\begin{tabular}{|c|c|}
\hline MAGNA & Research Article \\
MEDIKA & Berkala Ilmiah Kedokteran dan Kesehatan \\
\cline { 2 - 3 } & Journal Page: https://jurnal.unimus.ac.id/index.php/APKKM
\end{tabular}

\title{
Comparison of Platelet Levels between Preeclampsia and Eclampsia Patients at Wiyung Sejahtera Hospital, Surabaya
}

\author{
Reyke Fortuna Maudy Sintya ${ }^{1}$, Ninuk Dwi Ariningtyas ${ }^{2}$, Annisa Nurida ${ }^{3}$
}

1,2,3) Fakultas Kedokteran, Universitas Muhammadiyah Surabaya

\begin{tabular}{l}
\multicolumn{1}{c}{ Article Info } \\
\hline Article history: \\
Received 14 December 2020 \\
Revised 29 December 2020 \\
Accepted 06 January 2021 \\
Available online 01 February 2021 \\
\hline Keywords: \\
Platelets, Preecklampsia, \\
Eclampsia \\
\hline Correspondence: \\
reykefortuna94@gmail.com \\
\hline
\end{tabular}

How to cite this article:

1. Sintya RFM, Ariningtyas ND, Nurida A. Comparison of Platelet Levels between Preeclampsia and Eclampsia Patients at Wiyung Sejahtera Hospital, Surabaya. MAGNA MEDICA Berk Ilm Kedokt dan Kesehat. 2021;8(1):10-17

\begin{abstract}
Background: Indonesia is a developing country with a high maternal mortality rate (MMR) and perinatal mortality, the third highest in ASEAN and the second highest in the South East Asian Nation Regional Organization. In pregnancy hypertension has been proven that oxidants, especially if increased fat peroxide will damage endothelial cells called endothelial dysfunction. Vasospasm that occurs also induces platelet integration and endothelial damage which adds to the contribution in maintaining platelet dysfunction and triggering the use of platelets. Thrombocytopenia is the most important sign of the severity of preeclampsia.
\end{abstract}

Objective: to determine the comparison of platelet levels in patients with preeclampsia with eclampsia.

Methode: This study was observational cross sectional method. The sample in this study was a total sampling, using purposive sampling of patients with preeclampsia and eclampsia at the Wiyung Sejahtera Hospital in January-December 2019. The instrument used was using secondary data of medical records of patients.

Results: Patients with preeclampsia have a minimum platelet level of $301,000 / \mathrm{mm} 3$, a maximum of $415,000 / \mathrm{mm} 3$, and an average of $351,733.33 / \mathrm{mm} 3$ with a standard deviation of $33,552.66 / \mathrm{mm} 3$. Patients with eclampsia have a minimum platelet level of $122,000 / \mathrm{mm} 3$, a maximum of $281,000 / \mathrm{mm} 3$, and an average of $209,200 / \mathrm{mm} 3$ with a standard deviation of $42,465.45 / \mathrm{mm} 3$. There are significant differences in platelet levels of patients with preeclampsia with eclampsia $(\mathrm{p}<0.05)$.

Conclusion: there is a significant difference between the platelet levels of patients with preeclampsia and eclampsia. 


\section{PENDAHULUAN}

Delapan juta perempuan/tahun mengalami komplikasi kehamilan dan lebih dari setengah juta diantaranya meninggal dunia, dimana 99\% terjadi di Negara berkembang. Angka kematian akibat komplikasi kehamilan dan persalinan di Negara maju yaitu 1 dari 5000 perempuan, dimana angka ini jauh lebih rendah dibandingkan di Negara berkembang, yaitu 1 dari 11 perempuan meninggal akibat komplikasi kehamilan dan persalinan

Indonesia adalah contoh negara berkembang yang memiliki tingkat kematian Ibu (AKI) dan kematian perinatal tinggi ialah tingkat nomor tiga di ASEAN dan paling tinggi nomor di wilayah Asia Tenggara (South East Asian Nation Regional

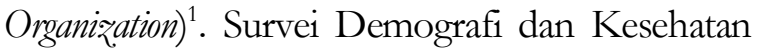
Indonesia (SDKI) tahun 2012 memperlihatkan "Peningkatan signifikan AKI di Indonesia sebesar $\pm 57 \%$ yaitu dari 228 per 100.000 . Kelahiran Hidup $(\mathrm{KH})$ pada tahun 2007 menjadi 359 per 100.000 KH." Tingkat tersebut jauh dari yang diharapkan dari target Rencana Pembangunan Jangka Menengah Nasional (RPJMN) tahun 2010- 2014 yaitu "AKI 118 per 100.000 KH, target MDG's (Millenium Development Goals) tahun 2015 yaitu 102 per 100.000 KH. Sedangkan target SDG's (Sustainable Development Goals) tahun 2030 yaitu AKI 70/100.000 KH²”.

Tingkat kematian Ibu (AKI) pada tahun 2012 di Provinsi Jawa timur ialah 97,41 per $100.000 \mathrm{KH}$ yang mengalami penurunan, menjadi 97,39 per 100.000 KH pada tahun 2013 dan 93,52 per Reyke Fortuna Maudy Sintya ${ }^{1}$, Ninuk Dwi Ariningtyas ${ }^{2}$, Annisa Nurida ${ }^{3}$ 
target MDG's (Millenium Development Goals) tahun 2015 yaitu 102 per 100.000 KH. Sedangkan target SDG's (Sustainable Development Goals) tahun 2030 yaitu AKI 70/100.000 KH²."

Tingkat kematian Ibu (AKI) pada tahun2012 di Provinsi Jawa timur ialah 97,41 per $100.000 \mathrm{KH}$ yang mengalami penurunan, menjadi 97,39 per 100.000 KH pada tahun 2013 dan 93,52 per 100.000 KH pada tahun $2014^{3}$. Faktor kematian terutama pada ibu di Jawa Timur karena preeklampsia/ eklampsia yang mengalami peningkatan dalam tahun 2010-2012. Peluang kejadian preeklampsia/eklampsia di Provinsi Jawa Timur pada tahun 2010 sebesar 26,92\% yang meningkat menjadi 27,27\% pada tahun 2011 dan $34,88 \%$ pada tahun $2012^{3}$. Di Surabaya angka kejadian preeclampsia pada tahun 2015 adalah 1145 kasus dan meningkat menjadi 1411 kasus di tahun 2016 ${ }^{4}$. Menurut Robert (2013) “terdapat sekitar 10\% ibu yang mengalami hipertensi akibat kehamilan; diantaranya 3-4\% mengalami preeklampsia, $5 \%$ hipertensi dan 1-2\% hipertensi kronik ${ }^{5} . "$ Pada kehamilan hipertensi sudah terbukti bahwa oksidan, khususnya jika peroksida lemak meningkat akan merusak sel endotel yang dsebut disfungsi endotel. Yang dapat mengakibatkan gangguan prostaglandin, agregasi sel-sel trombosit. Agregasi trombosit ini memproduksi tromboksan (TXA2) yaitu suatu vasokonstriktor kuat 6 .

Eklampsia adalah kejang yang ditandai dengan preeclampsia.Di Indonesia kejadian eklampsia merupakan penyebab kematian ibuk tertinggi kedua setelah perdarahan.Kejadian eklampsia di jawa timur khususnya disurabaya sama dengan preeclampsia. Kejadian eklampsia tiap tahunnya meningkat. Difungsi endotel pembuluh darah mengakibatkan penurunan fungsi sejumlah organ. Penurunan fungsi organ itu menyebabkan bebagai perubahan dalam kehamilan, salah satunya yaitu trombosit.

\section{METODE PENELITIAN}

Penelitian ini menggunakan metode Cross Sectional dengan pendekatan observasional. Populasi dalam penelitian ini adalah semua pasien yang pernah periksa di poli kandungan Rumah Sakit Wiyung Sejahtera Tahun 2019. Sampel pada penelitian ini total sampling pasien preeclampsia dan eklampsia bulan januari-desember 2019. Pengambilan sampel diambil dari pasien yang memenuhi kriteria sebagai berikut :

a. Kriteria Inklusi

1. Pasien yang terdiagnosa Preeklampsi usia 34-38 minggu

2. Pasien yang terdiagnosa Eklampsia usia 34-38 minggu

b. Kriteria Eksklusi

1. Pasien Preeklampsia usia $<34$ minggu

2. Pasien Eklampsia usia $<34$ minggu

Teknik pengambilan sampel dalam penelitian ini adalah purposive sampling. Instrumen yang digunakan adalah menggunakan data sekunder rekam medis pasien yang disertai dnegan lembar pengumpulan data. Analisa data dilakukan dengan analisa univariat dan analisa bivariat. Uji yang 
digunakan yaitu McNemar dengan menggunakan aplikasi SPSS versi 25.

\section{HASIL}

\section{Kadar Trombosit Pasien Preeklampsia dan}

\section{Eklampsia}

Penelitian dilakukan dengan menggunakan 30 sampel penelitian yang terdiri dari 15 pasien preeklampsia dan 15 pasien eklampsia. Data kadar trombosit pada kedua kelompok tersebut dapat disajikan dengan menggunakan chart pada gambar 1. Kadar trombosit pada pasien preeklampsia dan eclampsia dapat dilihat pada tabel 1

Tabel 1 Deskripstif Kadar Trombosit Pasien Preklampsia dan Eklampsia

\begin{tabular}{lccccc} 
Kelompok & N & Minimum & Maksimum & Rata-rata & Standar Deviasi \\
\hline Preeklampsia & 15 & 301.000 & 415.000 & $351.733,33$ & $33.552,66$ \\
\hline Eklampsia & 15 & 122.000 & 281.000 & $209.200,00$ & $42.465,45$ \\
\hline
\end{tabular}

Sumber : Hasil Analisis SPSS 20

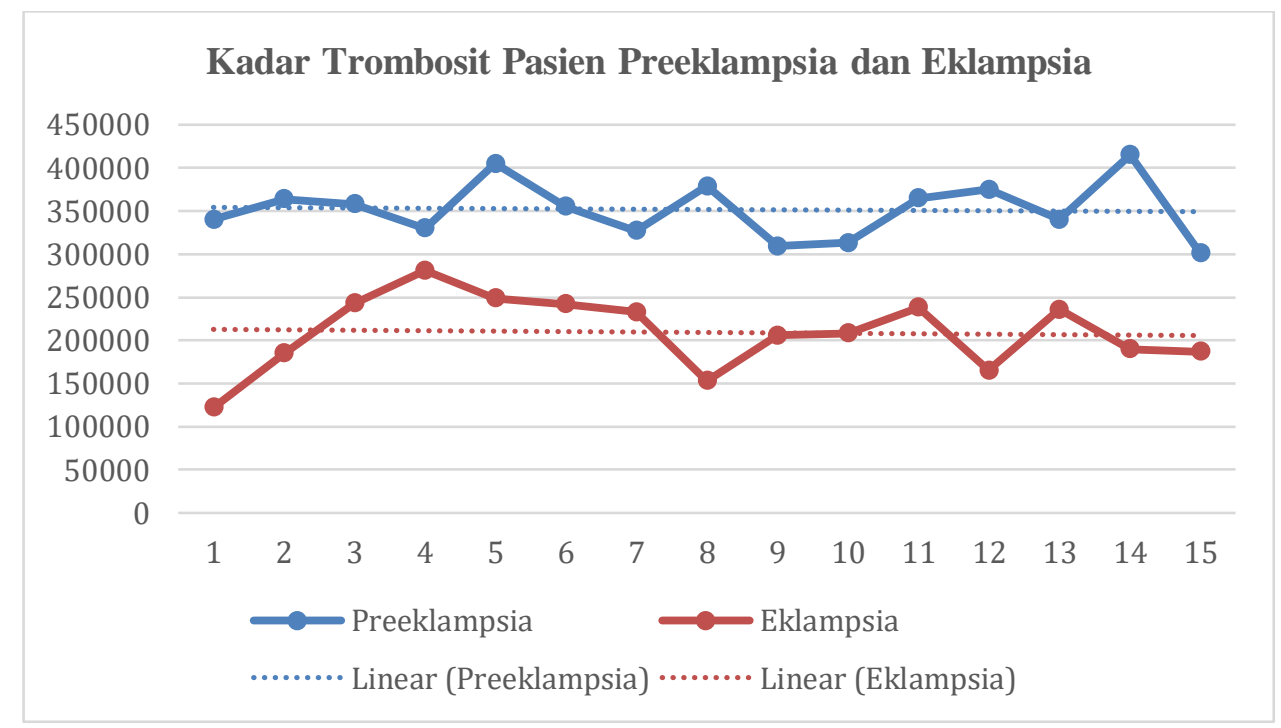

Gambar 1 Kadar Trombosit Pasien Preeklampsia dan Eklampsia

Tabel 2 Uji Normalitas Kadar Trombosit

\begin{tabular}{lllll}
\hline Kelompok & $\mathbf{N}$ & Statistics & $\mathbf{P}$ & Keterangan \\
\hline Preeklampsia & 15 & 0,969 & 0,839 & Normal \\
\hline Eklampsia & 15 & 0,963 & 0,743 & Normal \\
\hline
\end{tabular}

Hasil uji normalitas dengan uji Shapiro Wilk preeklampsia dan eclampsia masing-masing menunjukkan nilai signifikansi pada kelompok sebesar 0,839 dan 0,743 ( $p>0,05)$. Hal ini 
menunjukkan bahwa kedua kelompok memiliki kadar trombosit yang berdistribusi normal. Sehingga analisis dilanjutkan dengan uji Independent $\mathrm{t}$.
Tabel 3 menunjukkan nilai $\mathrm{F}$ hasil uji Levene sebesar 0,925 dengan nilai signifikansi sebesar $0,344$ ( $p>0,05)$. Hal ini menunjukkan bahwa kadar trombosit kedua kelompok homogen. Sehingga asumsi homogenitas terpenuhi.

Tabel 3 Uji Homogenitas

\begin{tabular}{|c|c|c|c|}
\hline Kelompok & F & $\mathbf{P}$ & Keterangan \\
\hline Preeklampsia & \multirow{2}{*}{0,925} & \multirow{2}{*}{0,344} & \multirow{2}{*}{ Homogen } \\
\hline Eklampsia & & & \\
\hline
\end{tabular}

Perbedaan Kadar Trombosit Pasien 10,200 ( $|t| \geq 1,96)$ dan nilai signifikansi yang Preeklampsia dan Eklampsia

Sesuai hasil analisis dengan menggunakan uji diperoleh sebesar $0,000(\mathrm{p}<0,05)$. Jadi, bisa ditarik Independent $t$, diperoleh nilai $t$ hitung sebesar kesimpulan bahwa ada perbedaan yang signifikan kadar trombosit pasien preeklampsia dan eklampsia.

Tabel 4 Perbedaan Kadar Trombosit Pasien Preklampsia dan Eklampsia

\begin{tabular}{lcccc}
\hline Kelompok & $\mathbf{N}$ & Rata-rata & t & P \\
\hline Preeklampsia & 15 & $351.733,33$ & & \\
\cline { 1 - 2 } Eklampsia & 15 & $209.200,00$ & 10,200 & 0,000 \\
\hline
\end{tabular}

\section{PEMBAHASAN}

Perbedaan kadar trombosit kedua kelompok dilakukan dengan menggunakan uji Independent t, karena telah menenuhi asumsi normalitas dan homogenitas. Apabila nilai $t$ hitung yang didapatkan lebih dari 1,96 $(|t| \geq 1,96)$ dan nilai signifikansi kurang dari $0,05(\mathrm{p}<0,05)$ maka dapat dikatakan ada perbedaan yang signifikan pada kedua kelompok tersebut. Sesuai hasil analisis dengan menggunakan uji Independent t, diperoleh nilai t hitung sebesar 10,200 ( $|t| \geq 1,96)$ dan nilai signifikansi yang diperoleh sebesar 0,000 $(\mathrm{p}<0,05)$. Jadi, bisa ditarik kesimpulan bahwa terdapat perbedaan yang signifikan kadar trombosit pasien preeklampsia eklampsia.

Penelitian ini menunjukkan adanya perbedaan yang signifikan pada jumlah trombosit antara pasien preeklampsia dan eklampsia, dimana kadar trombosit pasien dengan preeklampsia terbih tinggi dibandingkan kadar trombosit pasien eklampsia. Data menunjukkan bahwa peradangan pada mikrovaskular adalah faktor penting yang berkontribusi pada patogenesis preeklamsia. 
Abnormal plasentasi dianggap bertanggung jawab dari pelepasan mikropartikel dan faktor antiangiogenik ke dalam sirkulasi sistemik maternal.Faktor-faktor yang larut ini memulai aktifasi trombosit, memproduksi sitokin inflamasi, dan disfungsi endotel vaskular ${ }^{7}$. Meskipun trombosit yang beredar berada dalam keadaan beristirahat, ketika mereka terkena mediator larut atau mi-kropartikel di pembuluh darah meradang seperti pada preeklamsia, trombosit diak-tifkan oleh pengikatan mediator pada re-septor permukaan mereka.Setelah aktifa-si, trombosit melepaskan berbagai molekul terlarut dan adhesi seperti CD40L, platelet endothelial cell adhesion molecule-1 (PECAM-1/CD31). Ketika me-diator larut melepaskan ke dalam lingku-ngan inflamasi mereka memicu interaksi antara trombosit, leukosit, dan sel endotel (ECs). Cross-talk antara trombosit dan leukosit merangsang migrasi neutrofil ke situs inflamasi dengan membentuk agregat trombosit-leukosit. Ikatan trombosit leukosit meningkatkan permeabilitas endotel dan menginduksi produksi sitokin inflamasi sehingga menyebabkan amplifikasi morfologi dan respon inflamasi molekuler.

Dalam kondisi fisiologis normal, trombosit yang beredar berada dalam keadaan diam. Endotel pembuluh darah yang sehat mengeluarkan beberapa mediator seperti nitrat oksida $(\mathrm{NO})^{9}$, dan adenosine yang menghambat aktifasi trombosit, adhesi ke endotel. Namun, peradangan pada endotel mengakibatkan produksi dari mediator pelindung ini berkurang ${ }^{10}$. Sebaliknya, kadar metabolit NO dan adenosin meningkat pada pasien preeklamsia secara paralel terhadap aktifasi trombosit yang signifikan dibandingkan dengan kehamilan normotensif. Konsentrasi NO meningkat di sirkulasi feto-plasenta pada preeklamsia. Peningkatan kadar NO berkompensasi lanjut terhadap aktifasi trombosit pada wanita preeklamsia.

Trombosit yang beredar terkena faktor larut seperti mediator lipid, sitokin, dan kemokin yang dilepaskan oleh leukosit dan sel endotel yang diaktifkan dikarenakan inflamasi pembuluh darah.Akumulasi dari mediator ini memunculkan respon aktifasi yang ditandai oleh degranulasi granul-granul trombosit (9). Kadar yang lebih tinggi dari p-selektin dapat mengkonfirmasi kehadiran aktifasi trombosit dan sel endotel pada preeklamsia.

Pada preeklamsi terjadi hyperkoagulasi baik pada sirkulasi maternal maupun plasental, pada keadaan ini mengakibatkan penurunan faktor kuagulasi dan trombosit. Trombopoiti adalah megakariosit stimulating faktor.Pada ibu dengan hipertensi menyebabkan penurunan megakariosit pada janin, menyebkan tomboitin tidak meningkat yang dapat menyebabkan trombositopeni. Dikatakan megakariosit yang rendah mempunyai resiko terjadinya asfiksia, akan tetapi mekanisme yang pasti belum diketahui. Hipertensi dapat menyebabkan dehidrasi intravaskuler, vasospasme sehingga terjadinya dehidrasi jaringan, yang akan menyebabkan kerusakan endotel, koagulasi / hiperkoagulasi meningkat, 
terjadi trombositopeni, penurunan kadar fibrinogen, terjadi perdarahan intravasculer dan DIC. Makin lamanya proses penyakit dan makin lamanya waktu antara terjadinya preeklamsi/ eklamsi dengan proses persalinan kadar trombosit makin rendah. Pada preeklamsi / eklamsi terjadi vasokonstriksi difus yang akan menyebabkan penurunan fungsi beberapa organ karena pendarahan dan oksigen pada organ tersebut menurun. Organ yang sering mengalami penurunan fungsi tersebut adalah unit fetoplasenter, ginjal dan otak. Gangguan fungsi ginjal berupa terjadinya penurunan perfusi dan filtrasi glomerolus, ditandai dengan peningkatan kadar ureum dan kreatinin darah.

Kadar trombosit merupakan parameter laboratorium yang penting pada preeklampsia. Hemoglobin dan hematokrit dapat meningkat karena adanya hemokonsentrasi, atau bisa juga terjadi anemia sekunder karena hemolisis pada kasus-kasus tertentu. Kadar leukosit, terutama neutrofil, meningkat karenamenggambarkan proses inflamasi yang terjadi pada preeklampsia /eklampsia. Kenaikan jumlah neutrofil juga dapat menggambarkan tingkat keparahan respon inflamasi pada preeklampsia berat. Trombositopenia terjadi karena adanya peningkatan aktivasi platelet dan koagulasi platelet akibat perlukaan pembuluh darah. Trombositopenia juga memudahkan terjadinya hemolisis dan fragmentasi eritrosit sehingga nilai $\mathrm{MCH}, \mathrm{MCV}$, dan MCHC, serta jumlah eritrosit juga berubah.
Penelitian ini tentang analisis pengaruh kadar trombosit, hematokrit, hemoglobin darah dan protein urin pada ibu preeklampsia /eklampsia terhadap nilai apgar bayi yang dilahirkan. Hasil penelitian tersebut menunjukkan ada hubungan yang signifikan antara kenaikan kadar hematokrit, penurunan kadar trombosit dan tingginya kadar proteinuria pada ibu preeklampsia dan eklampia dengan nilai apgar bayi.

Pada tahun 2010 penelitian di Surakarta menyebutkan bahwa kadar hematokrit semakin meningkat seiring dengan peningkatan derajat preeklampsia dan hasilnya menyatakan adanya hubungan bermakna antara peningkatan kadar hematokrit dengan peningkatan preeklampsia ringan menjadi preeklampsia berat. Namun peningkatan kadar hematokrit dengan peningkatan preeklampsia berat menjadi eklampsia tidak terdapat hubungan. Adapun penelitian yang dilakukan di medan didapatkan bahwa terdapat perbedaan bermaknakadar leukosit antara kehamilan normal dengan preeklampsia berat.

\section{KESIMPULAN}

Pasien dengan preeklampsia memiliki kadar trombosit minimum sebesar $301.000 / \mathrm{mm}^{3}$, maksimum sebesar $415.000 / \mathrm{mm}^{3}$, dan rata-rata sebesar $351.733,33 / \mathrm{mm}^{3}$ dengan standar deviasi sebesar 33.552,66/ $\mathrm{mm}^{3}$. Pasien dengan eklampsia memiliki kadar trombosit minimum sebesar $122.000 / \mathrm{mm}^{3}$, maksimum sebesar $281.000 / \mathrm{mm}^{3}$, dan rata-rata sebesar $209.200 / \mathrm{mm}^{3}$ dengan 
standar deviasi sebesar $42.465,45 / \mathrm{mm}^{3}$. Terdapat perbedaan yang signifikan antara kadar trombosit pasien preeklampsia dan eklampsia.

\section{DAFTAR PUSTAKA}

1. World Heath Organization. who.int [En ligne]. 2019. Maternal mortalityDisponible: https://www.who.int/news-room/factsheets/detail/maternal-mortality

2. Kementerian Kesehatan Republik Indonesia. Profil Kesehatan Indonesia tahun 2014. Jakarta: Kementerian Kesehatan Republik Indonesia; 2015.

3. Departemen Kesehatan Republik Indonesia. Profil Kesehatan Jawa Timur 2014. Jakarta: Departemen Kesehatan Republik Indonesia; 2015.

4. Prasetya PA. Hubungan Anemia Trimester Pertama dengan Preeklampsia pada Ibu Hamil di Puskesmas Sidotopo Wetan Surabaya. Universitas Airlangga; 2018.
5. Roberts JM, Bodnar L, Patrick TE, Powers RW. The Role of Obesity in Preeclampsia. Pregnancy Hypertens. 2011;1(1):6- 16.

6. Prawirohardjo S. Ilmu Kebidanan. Jakarta: Yayasan Bina Pustaka; 2011.

7. Cunningham FG. Obstetri Williams. Jakarta: EGC; 2012.

8. Zarbock A, Polanowska-Grabowska R, Ley K. Latelet-Neutrophil-Interactions: Linking Hemostasis and Inflammation. Blood Rev. 2007;21(2):99- 111.

9. Anas, Muhammad, and Uning Marlina. "Penggunaan Nitrovasodilator Sebagai Donor Oksida Nitrik Pada Preeklamsia." PROCEEDING. 2018.

10. Stokes H. Imagining Futures: Identity Narratives and the Role of Work, Education, Community and Family. Melbourne: Youth Studies Series; 2012. 